\title{
Collecting First-Generation Voices in Academic Libraries and Archives
}

\section{Blake Graham, Stefani Baldivia, William Cuthbertson, Kendall Leon, Jane Monson, and Jay Trask}

First-generation college students have a profound impact both inside and outside the classroom on the strategic goals of universities, yet in-depth, firsthand information about their experiences are difficult for researchers and university administrators to find. Oral histories are a data-rich method of collecting narratives that legitimize the perspectives of underrepresented communities whose stories are often absent from the written record. This article provides a brief overview of first-generation populations, a review of literature relating to the increasing involvement of libraries and archives in capturing and preserving the stories of underdocumented communities in the twenty-first century, and shares three case studies of first-generation initiatives at public universities in California, Colorado, and Nebraska.

\section{Introduction}

The National Center for Education Statistics (NCES) defines first-generation college students as those who are enrolled in postsecondary education and whose parents do not have any postsecondary education experience. ${ }^{1}$ Demographically, a higher percentage of first-generation students are Latinx or Black and come from lower-income households. ${ }^{2}$ First-generation students are also at a greater risk of dropping out due to a number of impeding factors, including conflicts with demands at home or work and the affordability of degree completion. Other obstacles to success include lower rates of college readiness, ${ }^{3}$ difficulty navigating organizational structures of the postsecondary environment, and social and cultural differences that may contribute to a lack of integration with peers. However, first-generation students speaking to their lived experiences have been classified as proactive, resourceful, goal-directed, optimistic, and selfreliant-characteristics that map well to academic success. ${ }^{4}$

\footnotetext{
*Blake Graham was formerly at the University of Nebraska-Lincoln and is currently Data Operations Specialist at the University of Colorado-Boulder; email: blake.graham@colorado.edu. Stefani Baldivia is Archivist at California State University, Chico; email: sbaldivia@csuchico.edu. William Cuthbertson is Instruction Coordinator and Undergraduate Engagement Librarian at California State University, Chico; email: wcuthbertson@csuchico. edu. Kendall Leon is Associate Professor of Chicano/Latinx Rhetoric at California State University, Chico; email: kleon1@csuchico.edu. Jane Monson is Digital Initiatives Librarian at the University of Northern Colorado; email: jane.monson@unco.edu. Jay Trask is Head of Special Collection at the University of Northern Colorado; email: jay. trask@unco.edu. @2021 Blake Graham, Stefani Baldivia, William Cuthbertson, Kendall Leon, Jane Monson, and Jay Trask, Attribution-NonCommercial (https://creativecommons.org/licenses/by-nc/4.0/) CC BY-NC.
} 
Libraries and archives play a vital role in supporting first-generation student success by providing targeted instruction and programming to address the specific needs of these students, including increasing students' awareness of first-generation identities, ${ }^{5}$ using nontraditional media to connect with students, ${ }^{6}$ and giving room for students to speak to lived experiences. More than just addressing academic needs, libraries are working to integrate firstgeneration students into university frameworks through the documentation and preservation of their experiences. Such an approach reflects a move in higher education to shift the focus from whether a student is "college ready" to whether or not the college is "student ready."7

This article provides case studies of collaborative first-generation initiatives involving libraries and archives at three academic institutions: the University of Northern Colorado (UNCO); the University of Nebraska-Lincoln (UNL); and California State University, Chico (CSUC). Each of these cases have in common the creation and collection of oral histories as instruments for student instruction, outreach, and engagement, as well as tools for building more inclusive collections. These case studies demonstrate a specific approach that campuses can take to 1) recognize student strengths, 2) give space to capture intersectional first-generation student identities, and 3) involve students in institutional restructuring, thereby including students as part of a larger "engaged community" on campus. ${ }^{8}$

College and university archives, as with many archival institutions, traditionally focus on the preservation and acquisition of records that document the existing power structure. University archives reflect the university's hierarchy; records documenting the presidents, trustees, significant faculty, and other groups that represent the voices of authority are typically contained within the collections. Student voices may exist within the archives in such materials as student newspapers and governance bodies, but libraries and archives should aim for broader representation of the student experience. Looking at the collections at UNCO, CSUC, and UNL, the archivists determined that first-generation students' voices in particular have long been missing from their collections.

\section{Background}

Since 1990, the National Center for Education Statistics (NCES) has collected data to better understand the differences between continuing-generation and first-generation student populations. The total degree-earning population in the United States has steadily increased from 21 percent in 1990 to 33 percent in 2015; but, within this same time span, the first-generation population has faced a range of challenges that have caused enrollment and degree completion rates to ebb and flow rather than increase in a positive direction. Between 1992 and 2000, first-generation students represented 22 percent of students entering postsecondary education. Among this population of first-generation students, 43 percent left the institution without a degree, compared to 20 percent of continuing-generation students. These findings indicate that first-generation students were twice as likely to leave postsecondary education without a degree. ${ }^{9}$ Furthermore, between 2002 and 2012, 33 percent of first-generation students dropped out of college within the first three years (compared to 26 percent of continuing-generation students). ${ }^{10}$ Other researchers have found that, between 2002 and 2012, first-generation students were less than half as likely to earn a bachelor's degree after high school as continuinggeneration peers ( $20 \%$ vs. $42 \%){ }^{11}$

In 2011, first-generation undergraduate enrollments at UNCO and CSUC were well below the national average of 33 percent ${ }^{12}$ ( 21 percent enrollment at $\mathrm{UNCO}^{13}$ and 18 percent at 


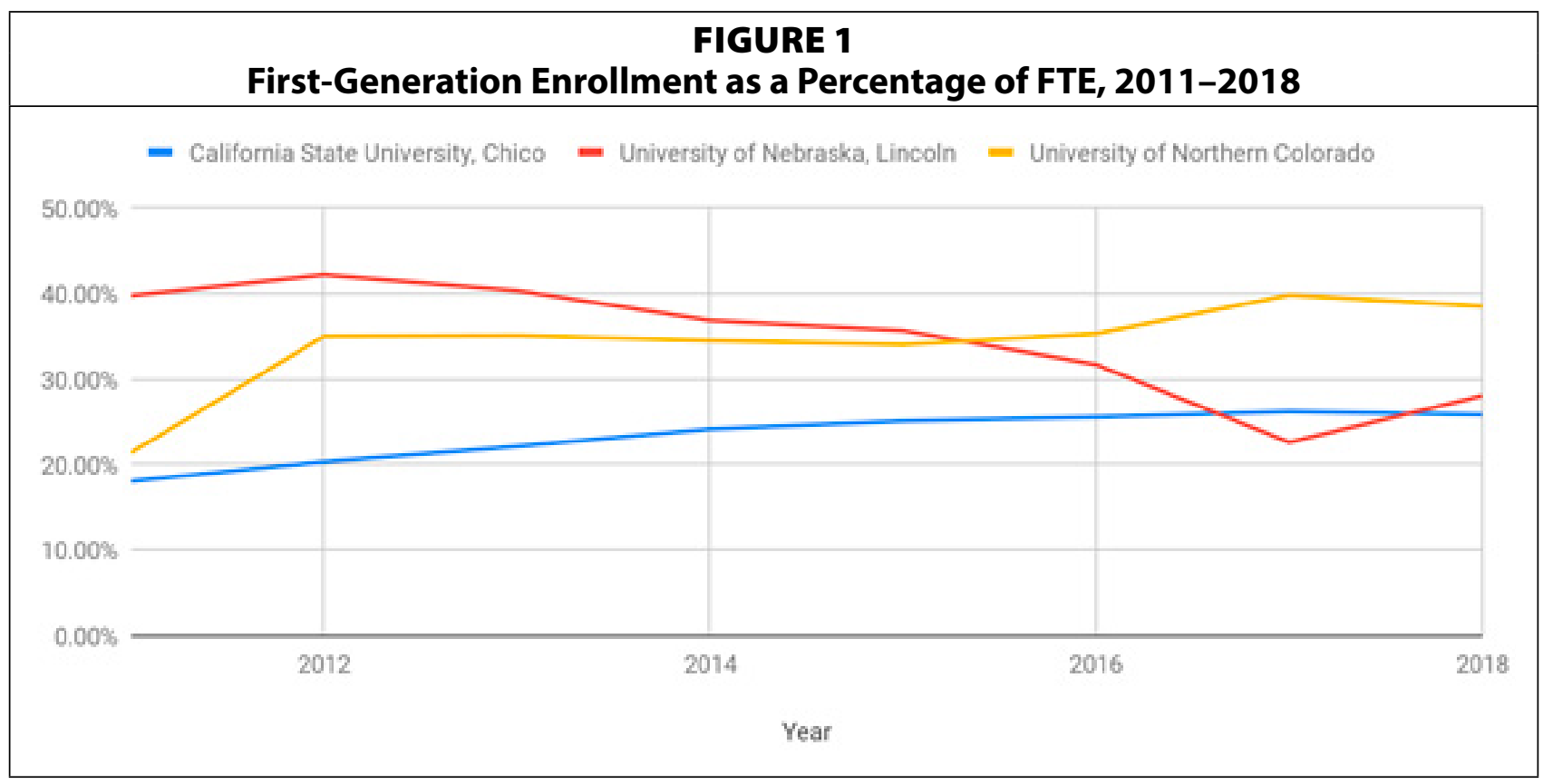

$\left.\mathrm{CSUC}^{14}\right)$. UNL counted 40 percent of its total undergraduate enrollment as first-generation in 2011. ${ }^{15}$ The 2011 average first-generation enrollment among all three universities was 26 percent. By 2018, however, the average enrollment rose to 31 percent following increases at CSUC to 26 percent and UNCO to 39 percent, and a considerable decrease at UNL to 28 percent (see figure 1).

\section{Literature Review}

The Center for First-Generation Student Success - an initiative of the National Association of Student Personnel Administrators and the Suder Foundation-emphasizes the critical importance of understanding the first-generation experience to turn perceived student deficits into educational opportunities. ${ }^{16}$ The collection of first-generation student oral history narratives is one way that academic libraries and archives can contribute to this shift, while simultaneously supporting larger institutional strategies to better reflect student demographics and increasing institutional awareness of growing first-generation communities. Such efforts also reflect a larger movement within library and information science professions toward greater inclusivity. Within the past decade, professional discourse on advocating for, as well as collecting and assessing, marginalized holdings has gained momentum. Recently, scholars have argued that the actions of practitioners should better reflect the core values of the profession, such as understanding and responding to archival silences, and proactively creating inclusive collection development policies and practices. In other words, many archivists are continuing to dissect the effects of complacent stewardship. The case studies described in this article provide examples of projects that attempt to achieve archival reconciliation toward first-generation students and reflect the changing role and responsibility of archivists.

\section{Inclusivity and Collection Development}

As Randall Jimerson argues in Archives Power, archivists have a unique role in shaping the knowledge of the past; therefore, they have a duty to examine their collecting activities. ${ }^{17}$ University archivists must determine which voices are silenced in their collections. John Straw 
described archival outreach to document student life as "serendipitous," as "much of student life is unorganized, individualized and transitory." 18 Straw urges archivists to be intentional in their efforts to gather and collect student perspectives through a collection development plan, articulating that "developing new documentation strategies, conducting oral history interviews, monitoring student electronic conferences, and even establishing an archival program dedicated to documenting student life are all innovative approaches being undertaken in academic archives." 19 Yet, even as Straw asserts that oral histories are an effective method for illustrating students' perspectives for preservation in the university archives, he warns that this method can be taxing on smaller repositories' already limited resources. Rather than archivists creating oral histories themselves, Straw suggests that "an alternative to archives staff doing oral histories on student life is to collect those done by other individuals." 20

In addressing challenges facing university archives to document modern society, Helen Willa Samuels notes that archivists must consciously coordinate new collecting areas and encourage communities, particularly student groups, to create resources on topics that help fill gaps in the documentary record. ${ }^{21}$ Samuels identifies several ways to accomplish this task, including engaging with students to create new collections that better represent student life such as diaries, oral histories, and photographic materials. Although this postcustodial stance is widely accepted in the profession, adopting inclusive collection development strategies remains a challenge for many university archives today.

In their survey of 470 students' perceptions of archival repositories, Jessica Wagner and Debbi Smith affirm the value of documenting student life but note the lack of "mechanics" offered in Samuels' book. ${ }^{22}$ Wagner and Smith offer readers several methods to acquire archival materials, including outreach to students, cross-campus networking strategies, and motivating students to create primary sources. Using a similar approach, Jenifer Becker applied a six-step iterative process to work with student groups to discuss donating to the archives. ${ }^{23}$ Becker argues that working with student groups to understand their interests, concerns, and critiques builds trust and transparency and provides a starting point for seeking donations. Both the Becker and Wagner and Smith articles build upon Samuels' notion to encourage archivists to document student life and pursue a better understanding of student groups. This effort can, in turn, better integrate students into the archive's lifecycle as donors and researchers.

Lae'l Hughes-Watkins writes of "reparative" archives bringing historically oppressed voices in from the margins. ${ }^{24}$ In her work on archival collections of Black student life at Kent State University, Hughes-Watkins recommends archivists adopt a "multi-pronged approach for engaging in social justice through reparative archival practices" 25 in a way that incorporates acquisitions and advocacy/promotion (in the form of exhibits and digitization) and uses acquired materials. The result of such reparative work is to create a feeling of inclusivity that brings marginalized groups more fully into the archival space. However, in criticizing the archival profession's ability to perform such reparative work, Jarrett Drake explains that, even though grassroots archival projects have a great amount of transformative potential, the archival profession seems to prefer passive, or even complicit, projects or initiatives to "ensure the viability and perpetuity of one's line of work." ${ }^{26}$ What, then, might radical collaboration $^{27}$ as a means to reparative archives look like, and how do archivists proactively confront long-standing biases?

The idea of and action toward radical collaboration is thoughtfully explained in Jennifer Bowers, Katherine Crowe, and Peggy Keeran's article encouraging librarians and archivists 
to proactively critique the Whiteness and inequality represented in academic archives. These authors use a combination of critical race theory (CRT) and the feminist ethic-of-care theory to acknowledge and assess the exclusivity and dehumanization in the profession's historical approach to collections. CRT emerged in the 1920s and 1930s in opposition to prevailing views of positivism and scientism by centering the experiences of people who are part of marginalized races or ethnicities. ${ }^{28}$ The ethics-of-care theory, on the other hand, is posited on voice and relationship; it focuses on being listened to and heard with respect, as well as the need to be responsive in new and growing relationships..$^{29}$ Bowers, Crowe, and Keeran adopt this form of interpersonal mutuality in libraries and archives by collecting, preserving, and providing access "without requiring community members to relinquish autonomy over their history, their ways of knowing, and their own narrative(s)." ${ }^{30}$

Other scholars support this stance and further argue that social justice initiatives in archives have overlooked more subtle, intangible forms of oppression because archivists have been focused on a legalistic, rights-based framework - a theoretical framework positing that records are used as "tools of legal accountability" to document the violation of human rights. ${ }^{31}$ A rights-based framework for libraries and archives is separate from, but not necessarily opposed to, the feminist ethic-of-care approach. Caswell and Cifor argue that both the rights-based and the ethics-of-care theories strengthen the professional commitment to social justice, but feminist ethics are a more inclusive model for collection development and envisioning a just society. ${ }^{32}$

Caswell carries this approach further with the feminist standpoint appraisal theory, challenging the concept of neutrality in the profession. She asserts archivists have both the power and responsibility to reverse dominant hierarchies, and that "feminist stand point epistemologies give us the tools to name and dismantle the oppression that has [historically] guided us." ${ }^{33}$

\section{Oral Histories as a Collecting Instrument}

James Fogerty defends the value of the accepted, if not always respected, oral history as a necessary means of obtaining significant perspectives that traditional archiving otherwise may not capture. Fogerty asserts that, particularly in the case of organizational records, oral histories "create a total fabric that brings the records to life and reveals the organization for what it is." ${ }^{34}$ Oral histories combat the elitist bias built into most archival collections by "extending documentation to groups and individuals not normally possessed of papers or who are outside the purview of most collecting agencies." ${ }^{35}$

Jessica Wagner Webster examines the frequency with which archivists have written about using oral histories to capture the stories of undocumented populations by analyzing articles published in The American Archivist during a 73-year period. Webster finds that, "while the archival literature champions [oral histories] as a tool to document underdocumented groups, very few articles actually illustrate how archivists conduct oral histories, particularly of these groups." ${ }^{\prime 36}$ Similar to the criticism of Helen Willa Samuels' book, information about the mechanics of collection development for oral histories is lacking; although many archivists participate in or help create oral histories, Webster's informal survey of current archival practitioners finds that few specifically focus on marginalized populations. ${ }^{37}$

A similar review conducted by Ellen Swain, looking at 50 years of archival, library, and oral history scholarship bolsters this view. It reveals there has been a move away from publication on documenting oral history strategy, while also reflecting "the need for archivists and 
librarians to collaborate with each other and with other professionals to discuss oral history issues and to build partnerships." 38

Michele Christian writes of a lack of substance and of breadth of perspective in the records documenting student life at the Iowa State University Library. As the largest group of any university community, students have experiences and perspectives that are significant to the institution's history, yet the documentation of student groups is sparse. When the documentation does exist, it often portrays the operational interests of the university and its employees and is rarely representative of student life and activities. ${ }^{39}$ In an effort to adjust this trend, Christian planned and developed the Iowa State University Oral History Project. The 2001 project's goals were simple: (1) focus on students currently enrolled - especially members of student organizations, unaffiliated students, nontraditional students, and international students; and (2) ensure the project's long-term continuity by limiting total interviewing capacity and avoiding operational stress. ${ }^{40}$

The need for more publications on strategic, reparative collection development focused on oral histories cannot be overstated. The literature suggests that archivists recognize the many layers of responsibility and ethical considerations, specifically (1) being proactively involved in inclusive collection development; (2) being conscientious educators mindful of the changing interests and perspectives of students; and (3) being willing to examine and take action against the unconscious bias that influences the efforts of practitioners. The following case studies explore the creation of oral histories to better document first-generation college students' experiences in higher education, using a reparative archival approach steeped in CRT and a feminist ethic of care.

\section{Case Studies}

\section{Building Curriculum around Student Voices at University of Northern Colorado Libraries}

UNCO is a medium-sized doctorate-granting institution with a full-time enrollment of approximately 12,000, situated in the quickly growing community of Greeley, Colorado. The undergraduate population of the university is 23 percent Latinx, 4 percent African American, 4.5 percent multiracial, and less than 4 percent Asian, Pacific Islander, and Native American. The university's most recent statistics show that approximately 45 percent of the undergraduate population are first-generation students. ${ }^{41}$

In addition to individual research consultations and one-shot instruction sessions, the university libraries offer several one-credit information literacy courses that focus on research techniques and hands-on library skills. Two of these courses, delivered by faculty in the Information Literacy \& Undergraduate Support (ILUS) department, are LIB 150: Introduction to Undergraduate Research and LIB 151: Research Skills for Beginning Researchers. Both courses are composed mainly of freshmen and sophomores, but LIB 151 is designed for students in the UNCO Honors Program while LIB 150 is targeted toward members of UNCO's first-generation student population. LIB 150 is offered in partnership with UNCO's Center for Human Enrichment (CHE) program, which supports the first-generation student population in the areas of curriculum and instruction, academic advising, tutoring, and educational technology.

The University Archives and Special Collections (ASC) department houses papers and records documenting institutional history, the literary careers of authors James A. Michener 
and Connie Willis, and materials related to regional history. The bulk of the university records come from administrative or faculty sources, but certain aspects of the student experience have been captured, particularly the student newspapers, yearbooks, and student representative council records. However, the bulk of these student records represent a student voice cultivated by university administration and faculty. ASC faculty and staff have been actively reaching out to student organizations and cultural centers to better reflect the diversity of student voice and experiences on campus.

In 2015, library faculty in ILUS, ASC, and digital initiatives collaborated on the development of a lesson plan to integrate appreciation for physical archives and their digital surrogates alongside the creation of digital primary sources by students. The goals of the project were twofold: 1) to introduce students to the primary source materials available in ASC and the library's digital repository, Archives \& Special Collections @ Digital UNC; and 2) to better capture and preserve the contemporary undergraduate student experience for the university archival record. The lesson was initially delivered to honors students in the fall 2015 section of LIB 151.

During the class period devoted to the lesson, the head of ASC and the digital initiatives librarian served as guest lecturers. They introduced students to digital and physical archives, providing insight into the purpose of archives, the various types of archival holdings, the process of materials selection, and the benefits of digitization. The head of ASC presented a primary source "show-and-tell" in which students were able to handle and contextualize physical archival objects within the scope of the university's history, and the digital initiatives librarian shared digital surrogates of the objects as they appear in the digital repository. Finally, the ILUS faculty member in charge of the course introduced the assignment, in which students worked outside of class in groups of two or three to conduct peer interviews. In the interviews, students relayed to each other their experiences coming to the university, expectations set for them by themselves and others, and how the university fit into their definition of self and their academic aspirations.

As part of the assignment, students were required to record their interviews and contribute them to the university archives. Most students opted to use their phones to create the recordings, but they also had the option of checking out digital recorders from the library or using the library's digital recording studio. The course instructor provided an abbreviated deed of gift form for students to fill out, which included language giving the archives permission to preserve the recordings in the digital repository. Students could opt out of making their recordings publicly available or impose a five-year embargo on the digital files. Most students in this pilot group as well as in subsequent iterations chose to make their interviews immediately available online.

In spring 2016, the project scope was expanded, and the assignment was integrated into both LIB 150 and LIB 151 courses. While instructors deemed the lesson a success in general, they observed that the honors students in LIB 151 displayed less engagement and appeared less invested than the CHE cohort in LIB 150. Anecdotal feedback from CHE students, who spoke enthusiastically about the project to other faculty and students outside of the class, reinforced this impression. Since the assignment seemed to resonate more with first-generation participants, project coordinators made the decision to embed it solely within the LIB 150 course in future semesters.

In 2018, the project evolved further from its origins when ILUS faculty redesigned the LIB 150 curriculum, resulting in the lesson being dropped from the syllabus. Far from be- 
ing a setback, this development laid the groundwork for the project to become a more fully integrated collaboration between the Libraries and CHE. The instructor of the CHE section of ENG 122: College Composition agreed to add it to the course curriculum starting in fall 2018, noting that it dovetailed nicely with the CHE program's theme, "Find Your Voice, Tell Your Story." While the assignment itself remains essentially the same, the lesson delivery was revamped to better fit the goals of a course focused on composition rather than research. The class lecture places less emphasis on primary sources and their use in research, and now includes a component on the purpose of oral histories and best practices for creating them. The transition from ILUS to CHE occurred relatively smoothly during the fall 2018 semester, and it has since become a regular feature of the ENG 122 curriculum.

\section{First-Gen Stories and Partnerships at the University of Nebraska-Lincoln Libraries}

UNL was chartered in 1869 and serves as both the land-grant and comprehensive public university for the state of Nebraska. Located in Lincoln, Nebraska, as the flagship campus for the University of Nebraska system, UNL is composed of 6,315 faculty and staff and more than 25,000 enrolled students. For the fall of 2018, the body of enrolled students is made up of $<1$ percent American Indian/Alaska Native, 3 percent Asian, 3 percent Black, 7 percent Hispanic, $<1$ percent Pacific Islander, 3 percent two or more races, and 75 percent White (non-Hispanic). The faculty body is predominantly White (78 percent), and 41 percent identify as female and 57 percent as male. As a fundamental component of the university's mission, UNL continues to strive for a culturally diverse student body, faculty, and staff reflecting the multicultural nature of Nebraska. ${ }^{42}$

UNL has developed several different programs and initiatives geared toward and developed by first-generation students, staff, and faculty. The First-Generation Nebraska (FGN) initiative is a broad network that links first-generation student scholars with faculty and staff who self-identify as first-generation college scholars or advocates of the first-generation community. Established in 2017 by the Office of the Executive Vice Chancellor, many of the activities in FGN include creating and distributing first-generation ephemera and "swag," organizing networking and social receptions, hosting a meal-and-mentoring program, and campaigning to recognize UNL faculty and staff who were first-generation college scholars themselves. The FGN Advisory Board-composed of student scholars, faculty, and staffgathers monthly during fall and spring semesters to plan and coordinate a range of activities and provide feedback on these initiatives to the Executive Vice Chancellor's Office.

First Husker, a program managed by the First-Year Experience department and originally established in 2015, is a component of FGN that introduces first-generation scholars to academic, social, and financial resources and opportunities. These First Husker student scholars come to UNL the week before fall semester begins to engage in a four-day event to help ease their adjustment to college life and build a foundation for academic success. They meet with a variety of faculty and staff in interactive workshops, receive tips and advice on how to start their college experiences, and enjoy social activities with other First Husker peers. After the event, these students have the opportunity to enroll in a ten-week seminar covering academic success in large classes, time management, financial literacy, diversity and leadership, and goal setting, in addition to touring campus resources and networking with other First Husker student scholars. As of July 2018, approximately 320 student scholars have participated in First Husker. 
The First-Gen Stories (FGS) project is also a part of FGN and is one of the newest additions to the university's range of programs and initiatives for the first-generation community. The FGS project itself-managed by staff and faculty in archives and special collections and First Husker - is an oral history and life story project that captures and preserves the experiences and interests of first-generation scholars, staff, and faculty at the main campus in Lincoln, Nebraska. Most of the project is currently organized within the ten-week seminar in First Husker, but plans are underway for facilitating stories by a broader first-generation community (including students, staff, faculty, alumni, and professors emeriti). In this initial phase of the FGS project, organizers have been developing a small series of oral history prototypes by first-generation students participating in First Husker. These brief stories are compiled and shared at major First Husker events and then deposited into the archives.

The interviewing environment for FGS is intended to be more relaxed and informal, and the scheduling process is dependent on the individual student's initiative. Interviewees are encouraged (but not required) to schedule a time to create their videos using the one-button studio located in the learning commons area of Love Library. Alternatively, interviewees may create videos with personal devices as well, and then email or transfer the finalized video to archives and special collections. Any student interested in this project is encouraged to visit the project's LibGuide online, which offers instructions for interviews, a list of starter questions to begin the interview, and a frequently asked questions section..$^{43}$ Once the recordings are complete, participants are asked to complete a deed of gift and submit their work. The stories will be added to a first-generation collection in the university archives and made available online through the library's image and multimedia content management system.

The FGS project organizers continue to encourage folks to participate in the project during FGN events and activities. In some cases, it is important to explain the benefits of an oral history project not just to prospective participants, but to stakeholders and administrators tied to the university archives department. For example, proactively collecting first-generation narratives strengthens the existing collection development strategy in the archives because it replaces passive records transferring methods with an approach that empowers communities to participate in and reflect on the records creation process.

In fall 2018, a total of 263 graduate, 75 professional, and 5,507 undergraduate first-generation students were enrolled at the campus in Lincoln. ${ }^{44}$ Only 14 percent of these first-generation students participate in a Greek student organization. Without a new partnership between the university archives and First Husker to create new collections, the majority of archival collections representing student life would continue growing in the form of opportunistic donations by select, long-standing Greek student organizations - a collecting approach that hardly represents the first-generation experience. In addition, university administrators interested in creating programs to improve enrollment and degree-completion rates appreciate that FGS interviews provide insightful information about individual first-generation experiences. Firstgeneration oral histories can offer layered perspectives and experiences, which contrast with statistical tabular data gathered by enrollment and admissions offices. Although statistical information can be helpful in understanding first-generation student enrollment, disciplines studied, and dropout and success rates, students' oral histories provide experiential information, including backgrounds and interests, campus experiences, and expressed concerns. This experiential information can be incredibly helpful to administrators, especially when planning for long-term, sustainable programs designed specifically for the first-generation 
student population. Considering this population is often at least one-quarter to one-third of incoming freshmen, using first-generation stories for positive changes on campus inevitably leads to improving students' ability to engage with campus resources, adapt to academic life and, most importantly, succeed in their academic pursuits.

\section{First-Gen Experiences of Campus Groups at California State University, Chico}

California State University, Chico was established in 1889 and is the second oldest institution of the 23 colleges in the California State University system. Despite the campus' historical standing, the Special Collections Department was not established until 1965, nearly 80 years after the campus' creation. Materials that document the Chico State campus have been captured opportunistically as faculty and administrators have retired; therefore, the bulk of historic materials illustrate a perspective that is male, white, and socioeconomically privileged.

Currently, the school is led by the first openly gay president within the California State University system, as well as the first woman president in its history. ${ }^{45}$ However, according to a 2018 report from the California Faculty Association, 76 percent of tenured faculty at Chico State are White, placing the campus as the third least-diverse within the CSU system, where on average 60 percent of faculty are White. ${ }^{46}$ CSUC's senior leadership is also predominantly homogenous (86 percent White), which does not reflect the demographics of the current student population or the state of California. ${ }^{47}$ CSUC achieved the federal designation of Hispanic Serving Institution in 2015, which means 25 percent of Chico State students identify as Hispanic and at least 50 percent receive financial aid. ${ }^{48}$ Further, the CSUC Office of Institutional Research reported in 2018 that 54 percent of the student population was female and consisted of 57 percent historically underrepresented groups. ${ }^{49}$ In 2018, 46 percent of CSUC's incoming freshmen were first-generation students. ${ }^{50}$

The cultural dissonance between CSUC's administrative history and its current student makeup has become increasingly difficult for staff and faculty within CSUC's Meriam Library and campus academic departments to ignore. Mirroring Christian's summation of university archives at Iowa State University, archivists and librarians at the Meriam Library in the Special Collections and University Archives (SPC) and Research, Instruction, and Outreach (RIO) departments have found a dearth of student perspectives in the historic and contemporary archives of Chico State. ${ }^{51}$ Faculty in the Department of English have similarly worked to build a student-driven chronicle of the academic programs and social and cultural institutions of the campus and surrounding area - institutions that are underrepresented in the university's archival history. This three-pronged solution was proposed: (1) name the problem of homogeneity in archives; (2) provide students with tools to disrupt the dominant narrative; and (3) empower them to use their own voices to describe their experiences as first-generation scholars at a predominantly White institution.

The SPC department developed the Chico Archives Toolkit, or CAT project, in fall 2017. Applying Drake's critique of archival passivity, SPC designed the CAT project to help elevate undergraduate students' archival awareness. Through this critique, students involved in campus organizations could begin to see themselves as records creators, cultural workers, and historical participants on the Chico State campus.

Following Samuels' call to action, the SPC department envisioned the CAT project as an opportunity to facilitate collection development, increase and diversify the holdings that 
represent student perspectives, and promote the work and role of the campus' university archives. The approach was to coordinate workshops for each semester of the 2017-2018 academic year, inviting student organizations and clubs to participate. SPC partnered with the campus' Student Life and Leadership office, who provided a cash incentive of $\$ 25$ to any student organization that registered and attended the CAT workshop.

In the workshop, SPC archivists shared the function of university archives, articulated the problem of underdocumented communities, and emphasized the potential of student organizations as cultural workers. The CAT project empowers students to see themselves as records creators, where the primary sources created from their nonacademic experiences can be placed in the campus' historical archives, and their role as students is integral to the function of the campus. Toward that effort, SPC offered records management best practices and preservation guidance. Participants also received a CAT BOX, consisting of a flash drive for storing electronic records, acid-free folders, and a lignin-free metal-edge document box for long-term storage of print materials.

In spring 2018, the CAT workshop was part of the scheduled program for the FirstGeneration Staff and Faculty Association's event, 1st GEN Symposium: We Are Here. Archivists altered the workshop to publicize the CAT project through on-campus professionals.

After the symposium, faculty at Meriam Library and in the English department embedded the CAT project into an assignment for first-year, first-generation college students enrolled in the English 130: Academic Writing course. This course is cross-listed with the Educational Opportunity First-Year Experience program, and English faculty designed the course to help students recognize rhetoric around them and refine their abilities around rhetorical analysis.

This "Digital Stories" assignment invited students to apply their knowledge of rhetoric and writing strategies to compose stories about Chico State students to be donated to the Meriam Library Special Collections department and preserved in the university archives. The mechanics of the assignment directed students to select a student club or support organization to document, gathering both print and born-digital materials, including audio interviews. Some of the organizations the students selected to document included campus support centers like the Equal Opportunity Program (EOP), Upward Bound, and the Dream Center, as well as the student activist organizations Students for Quality Education and the Gender and Sexuality Equity Center.

A Meriam Library archivist taught two instructional sessions with the ENG 130 course to help prepare students for the Digital Stories assignment. The first session was a presentation of the CAT workshop, emphasizing electronic records preservation practices. Students began collecting primary source materials and conducting interviews with representatives from campus organizations after the first instruction. During the second instructional session, students were presented with unprocessed collections from the university archives and were tasked with describing those materials. This session allowed the undergraduates to analyze the rhetoric of primary sources and consider the way rhetoric operates in institutional records.

After the first instruction session, students complained of not finding anything "interesting" or worthy of collecting. This was most common among students who were gathering primary source materials on campus organizations by which they were supported or of which they were a member. For example, students researching EOP lamented they had difficulty identifying an EOP student or staff member to interview, forgetting that all the students in the course were EOP participants. Once reminded, students conceded it had not occurred to 
them to interview each other or that their own experiences would be relevant to the project. The students genuinely did not believe that their perspectives or experiences of EOP were worth documenting. Caswell's feminist ethic approach to archives was most consequential during this phase of the project: that librarians, archivists, and professors fortify the inherent value of first-generation students' presence on college campuses, by "advocat[ing] for the inclusion of marginalized individuals [on campus] communities in the [university] archives." 52

In May 2018, materials gathered by the class were donated to the university archives. Undergraduate students who recorded audio interviews completed an oral history deed of gift to transfer the files to the university archives. Although an embargo process was discussed in the class, none of the students who agreed to be interviewed pursued the embargo option. In fall 2018, SPC student assistants created transcripts of the 14 digital audio recordings, which were then uploaded to the CSUC digital asset management system, ContentDM. The SPC archivist accessioned and described the gathered print and digital media materials to make them publicly available on the Chico State ArchivesSpace platform. All materials are now cataloged and available for research.

\section{Conclusion and Next Steps}

The case studies presented here describe first-generation oral history projects with different approaches and objectives, but in each example the feminist ethic-of-care theoretical framework guided the work of improving documentation of an underdocumented community. Each of the case studies advocates for facilitating the inclusion of first-generation experiences in the university archives, building trusted partnerships based on an ethic of care, and helping explore a practice of interpersonal mutuality. This is done by seeking out, creating, and including nondominant perspectives in our collections. ${ }^{53}$

Like the institutions discussed here, campuses across the United States are dedicating more time and energy to supporting and representing their first-generation student communities, leading to increased institutional awareness of these students and their specific needs. Libraries and archives remain in an excellent position to help drive this movement forward. There are compelling reasons for this momentum. As an opportunity in the campus community, first-generation stories are a way for students to get more involved in the document creation process, increase literacy around archival research, and contribute to the history of student affairs and experiences. Oral histories also support university administrators' efforts to improve first-generation retention rates because first-generation stories provide raw data on the interests, perspectives, and experiences of these students in a way that statistical or tabular data may not. As a data collection method, oral histories afford the opportunity for students to reflect on their complex identities as more than just first-generation. And last, as an opportunity to help practitioners shed archaic practices of previous generations, first-generation stories challenge passive collecting methods that often favor a White continuing-generation population and equip archivists to rethink collection development strategies.

The three case study campuses continue to navigate challenges in sustaining first-generation stories. Because the projects are primarily personnel-dependent and not (yet) funded as a permanent responsibility of the libraries, the long-term collecting strategy will inevitably change with shifting networking and communication lines. CSUC has been successful in launching a campus symposium, which has the potential to be expanded into a regional or national conference event for first-generation students. Large campus environments can seem overwhelming and unfamiliar for many first-generation students, so connecting first- 
generation communities across geographic spaces via conferencing and oral history storytelling can be powerful and liberating. At UNCO, as of fall 2019 the Student Voices collection housed within the digital repository contains 62 student interviews. ${ }^{54}$ The authors aim to bring the project to other groups on campus that focus on serving underrepresented student populations, such as the Latinx student cultural center. Similarly, the libraries at UNL are taking steps to trial interview sessions in different physical spaces across campus to attract oral histories from broader first-generation Nebraska groups, including underrepresented faculty and staff, alumni, and professors emeriti.

All three campuses continue to explore different ways to expand first-generation oral histories beyond the libraries and rethink how oral history initiatives receive funding and attention from administrative structures and groups. Additional research connecting the success of first-generation oral history projects to the overall retention of first-generation students would be a valuable addition to the research. While each campus has a different approach to collecting, preserving, and providing access to first-generation oral histories, these case studies provide practical insights into the endless possibilities for better documenting student life and activities and proactively building archival collections and campus partnerships that are better aligned with inclusivity and dependent on an ethic of care.

\section{Notes}

1. Jeremy Redford and Kathleen Mulvaney Hoyer, First-Generation and Continuing-Generation College Students: A Comparison of High School and Postsecondary Experiences, NCES 2018-009 (Washington, DC: National Center for Education Statistics, U.S Department of Education, 2017), https://nces.ed.gov/pubs2018/2018009.pdf [accessed 13 January 2020].

2. Redford and Hoyer, First-Generation and Continuing-Generation College Students.

3. Postsecondary National Policy Institute, "First-Generation Students Factsheet," https://pnpi.org/firstgeneration-students [accessed 21 June 2019].

4. Nancy J. Garrison and Douglas S. Gardner, "Assets First Generation College Students Bring to the Higher Education Setting," paper presented at the Association for the Study of Higher Education (ASHE) Annual Conference, Las Vegas, NV, November 2012.

5. Sara E. Whitley, Grace Benson, and Alexis Warsaw, First-Generation Student Success: A Landscape Analysis of Programs and Services at Four-Year Institutions, National Association of Student Personnel Administrators in Higher Education, Center for First-Generation Student Success (Washington, DC: U.S. Government Printing Office, 2018), 78.

6. Whitley, Benson, and Warsaw, First-Generation Student Success, 67.

7. Whitley, Benson, and Warsaw, First-Generation Student Success, 29.

8. Whitley, Benson, and Warsaw, First-Generation Student Success, 12.

9. Xianglei Chen, First-Generation Students in Postsecondary Education: A Look at Their College Transcripts, NCES 2005-171 (Washington, DC: U.S. Department of Education, National Center for Education Statistics, 2005), https:// nces.ed.gov/pubs2005/2005171.pdf [accessed 13 January 2020].

10. Emily Forrest Cataldi, Christopher T. Bennett, and Xianglei Chen, First Generation Students: College Access, Persistence, and Postbachelor's Outcomes: Stats in Brief, NCES 2018-421 (Jessup, MD: National Center for Education Statistics, 2018), 2-3.

11. Redford and Hoyer, First-Generation and Continuing-Generation College Students, 4.

12. Cataldi, Bennett, and Chen, First-Generation Students, 1.

13. Table 1, UNCO 2018 Fact Book, retrieved from https://www.unco.edu/institutional-reporting-analysisservices/fact-books.aspx.

14. California State University website, Institutional Research and Analyses, Fall Term Student Enrollment, Enrollment Summary, http://asd.calstate.edu/dashboard/enrollment-live.html.

15. Bethanie Zager (email correspondence to author, December 4, 2018).

16. "First-Generation Students: Approaching Enrollment, Intersectional Identities, and Asset-Based Success," Center for First-Generation Student Success, https://firstgen.naspa.org/blog/first-generation-students-approach- 
ing-enrollment-intersectional-identities-and-asset-based-success [accessed 21 June 2019].

17. Randall C. Jimerson, Archives Power: Memory, Accountability, and Social Justice (Chicago, IL: Society of American Archivists Press, 2009), 1-23.

18. John Straw, "From Classroom to Commons: Documenting the Total Student Experience in Higher Education," Archival Issues 19, no. 1 (1994): 19-29, http://www.jstor.org/stable/41101869.

19. Straw, "From Classroom to Commons," 20.

20. Straw, "From Classroom to Commons," 24.

21. Helen Willa Samuels, Varsity Letters: Documenting Modern Colleges and Universities (Lanham, MD: Society of American Archivists and The Scarecrow Press, Inc., 1998), 78.

22. Jessica Wagner and Debbi Smith, "Students as Donors to University Archives: A Study of Student Perceptions with Recommendations," American Archivist 75, no. 2 (2012): 543.

23. Jenifer Becker, "Bringing Student Voices into the University Archives: A Student Organization Documentation Initiative Case Study," In the Library with the Lead Pipe (December 2017).

24. Lae'l Hughes-Watkins, "Moving toward a Reparative Archive: A Roadmap for a Holistic Approach to Disrupting Homogenous Histories in Academic Repositories and Creating Inclusive Spaces for Marginalized Voices," Journal of Contemporary Archival Studies 5 (2018): 3.

25. Hughes-Watkins, "Moving toward a Reparative Archive," 11.

26. Jarrett Drake, "I'm Leaving the Archival Profession: It's Better This Way," On Archivy (June 26, 2017), https://medium.com/on-archivy/im-leaving-the-archival-profession-it-s-better-this-way-ed631c6d72fe.

27. Research Library Issues, no. 296 (Chicago, IL: Association of Research Libraries, 2018), https://doi.org/10.29242/ rli.296.

28. Jennifer Bowers, Katherine Crowe, and Peggy Keeran, "If You Want the History of a White Man, You Go to the Library': Critiquing Our Legacy, Addressing Our Library Collections Gaps," Collection Management 42 (2017): 1, 4, https://doi.org/10.1080/01462679.2017.1329104.

29. Carol Gilligan, interview by Webteam, "Ethics of Care: Sharing Views on Good Care," Critical Ethics of Care Foundation (July 16, 2011).

30. Bowers, Crowe, and Keeran, "If You Want the History of a White Man, You Go to the Library," 165.

31. Michelle Caswell and Marika Cifor, "From Human Rights to Feminist Ethics: Radical Empathy in the Archives," Archivaria 81 (2016): 26-27.

32. Caswell and Cifor, "From Human Rights to Feminist Ethics," 28.

33. Michelle Caswell, "Dusting for Fingerprints: Introducing Feminist Standpoint Appraisal," Journal of Critical Library and Information Studies 3, no. 1 (August 2020): 33.

34. James E. Fogerty, "Filling the Gap: Oral History in the Archives," American Archivist 46, no. 2 (Spring 1983): 153.

35. Fogerty, "Filling the Gap," 155.

36. Jessica Wagner Webster, "Filling the Gap: Oral Histories and Underdocumented Populations in The American Archivist, 1938-2011," American Archivist 79, no. 2 (Fall/Winter 2016): 255-56.

37. Webster, "Filling the Gap," 256.

38. Ellen D. Swain, "Oral History in the Archives: Its Documentary Role in the Twenty-First Century," American Archivist 66, no. 1 (Spring/Summer 2003): 156.

39. Michele Christian, "Documenting Student Life: The Use of Oral Histories in University Archives," Archival Issues 27, no. 2 (2002): 112.

40. Christian, "Documenting Student Life," 114-15.

41. "University of Northern Colorado Fall Census Enrollment Profile" (September 9, 2019), https://www.unco. edu/institutional-reporting-analysis-services/pdf/enrollment-stats/Fall2019CensusEnrollmentReportFinalV3.pdf [accessed 28 January 2020].

42. "Institutional Effectiveness and Analytics," University of Nebraska-Lincoln, https://iea.unl.edu/data-index. html [accessed 29 January 2020].

43. “First-Gen Stories Project" (January 21, 20200, https://unl.libguides.com/firstgenstories [accessed 29 May 2019].

44. Bethanie Zager (email correspondence to author, December 4, 2018).

45. Amelia Storm, "First Openly Gay CSU President 'A Step in the Right Direction'," The Orion (Chico, CA: March 30, 2016), https://web.archive.org/web/20160404212240/https://theorion.com/54901/news/first-openly-gaycsu-president-astep-in-the-right-direction/ [accessed 7 November 2018].

46. "A Snapshot of Bargaining Unit 3, Fall 2018," California Faculty Association, https://www.calfac.org/sites/ main/files/file-attachments/unit3snapshotposter.pdf [accessed 14 June 2019].

47. "Left Out: How Exclusion in California's Colleges and Universities Hurts Our Values, Our Students, and 
Our Economy," The Campaign for College Opportunity (March 2018), https://collegecampaign.org/portfolio/ left-out-report/ [accessed 14 June 2019].

48. "Becoming a Hispanic-Serving Institution," Chico State Today (December 14, 2015), https://today.csuchico. edu/becoming-a-hispanic-serving-institution/.

49. "Chico Facts," California State University, Chico, https://web.archive.org/web/20180223182327/, http://www. csuchico.edu:80/about/chico-facts.shtml [accessed 7 November 2018].

50. "Institutional Research and Analysis," California State University, Chico, http://asd.calstate.edu/dashboard/ enrollment-live.html [accessed 7 November 2018].

51. Christian, "Documenting Student Life," 111-24.

52. Caswell and Cifor, "From Human Rights to Feminist Ethics," 27.

53. Caswell, "Dusting for Fingerprints," 13.

54. University of Northern Colorado website, "Scholarship and Creative Works @ Digital UNC," https:// digscholarship.unco.edu/voices/. 